\title{
Rapid Assessment of U.S. Forest and Soil Organic Carbon Storage and Forest Biomass Carbon Sequestration Capacity
}

Open-File Repont 2009:1283
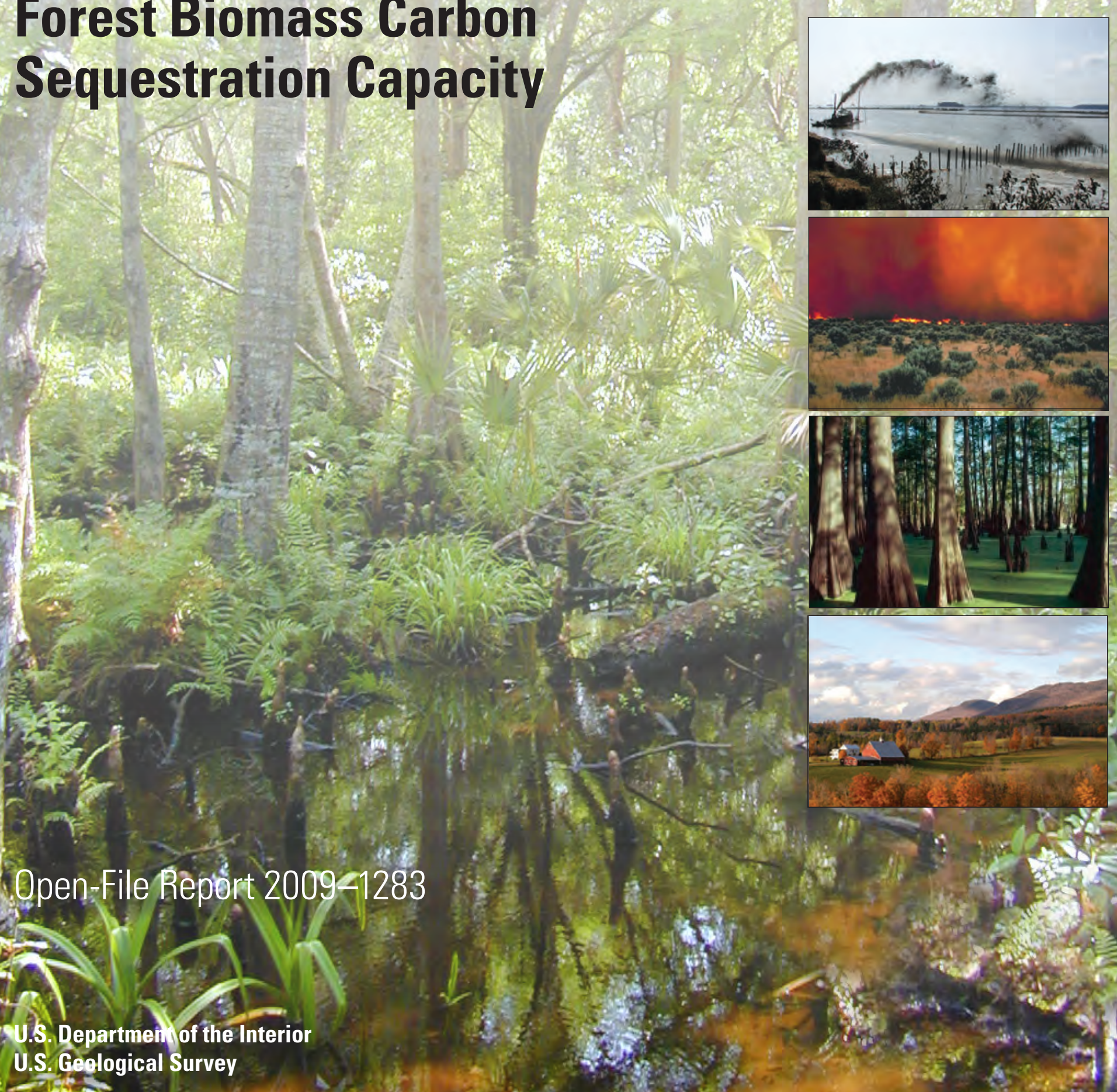

$$
\text { i.s. Gealogical survey }
$$


Front cover: Photograph by Heather Henkel (hhenkel@usgs.gov), U.S. Geological Survey. Looking through the cypress-maple swamp at Fern Forest, Florida, USA, April 20, 2000. 


\section{Rapid Assessment of U.S. Forest and Soil Organic Carbon Storage and Forest Biomass Carbon Sequestration Capacity}

By Eric T. Sundquist, ${ }^{1}$ Katherine V. Ackerman, ${ }^{1}$ Norman B. Bliss, ${ }^{2}$ Josef M. Kellndorfer, ${ }^{3}$ Matt C. Reeves, ${ }^{4}$ and Matthew G. Rollins ${ }^{5}$

${ }^{1}$ U.S. Geological Survey, Woods Hole, MA 02543.

${ }^{2}$ ASRC Research and Technology Solutions, Contractor to the U.S. Geological Survey EROS Data Center, Sioux Falls, SD 57198.

${ }^{3}$ Woods Hole Research Center, Falmouth, MA 02540.

${ }^{4}$ U.S. Department of Agriculture, Forest Service, Rocky Mountain Research Station, Missoula Fire Sciences Laboratory, Missoula, MT 59808.

${ }^{5}$ U.S. Geological Survey, EROS Data Center, Sioux Falls, SD 57198.

Open-File Report 2009-1283 


\section{U.S. Department of the Interior \\ KEN SALAZAR, Secretary \\ U.S. Geological Survey \\ Marcia K. McNutt, Director}

U.S. Geological Survey, Reston, Virginia: 2009

For more information on the USGS - the Federal source for science about the Earth, its natural and living resources, natural hazards, and the environment, visit http://www.usgs.gov or call 1-888-ASK-USGS

For an overview of USGS information products, including maps, imagery, and publications, visit http://www.usgs.gov/pubprod

To order this and other USGS information products, visit http://store.usgs.gov

Any use of trade, product, or firm names is for descriptive purposes only and does not imply endorsement by the U.S. Government.

Although this report is in the public domain, permission must be secured from the individual copyright owners to reproduce any copyrighted materials contained within this report.

Suggested citation:

Sundquist, E.T., Ackerman, K.V., Bliss, N.B., Kellndorfer, J.M., Reeves, M.C., and Rollins, M.G., 2009, Rapid assessment of U.S. forest and soil organic carbon storage and forest biomass carbon sequestration capacity: U.S. Geological Survey Open-File Report 2009-1283, 15 p., available at http://pubs.usgs.gov/of/2009/1283/. 


\section{Contents}

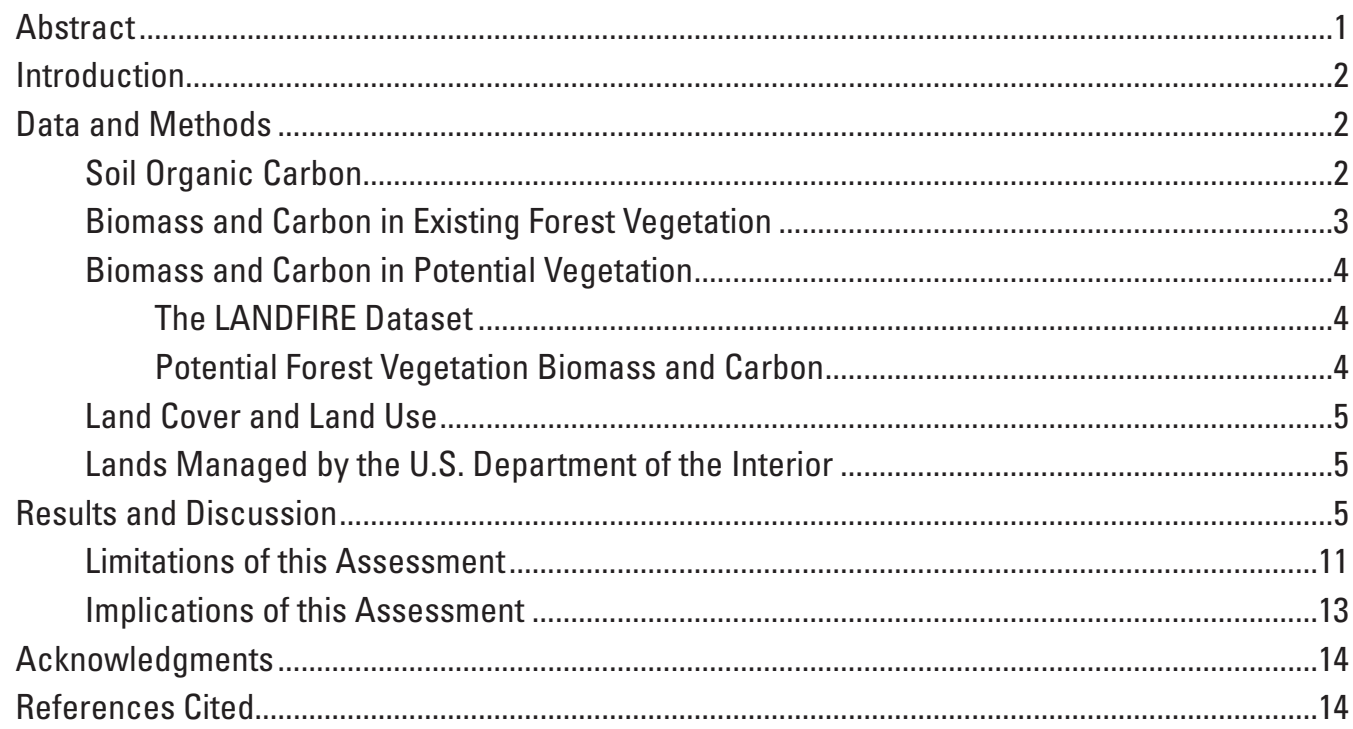

\section{Figures}

1-6. Maps showing-

1. Existing soil organic carbon, based on the SSURGO and STATGSO2 databases .....6

2. Existing forest biomass carbon, based on the USFS forest biomass map by Blackard and others (2008) ............................................................................

3. Hypothetical undisturbed forest biomass carbon sequestration capacity ..............8

4. Hypothetical historical forest biomass carbon sequestration capacity ....................

5. Land cover and land use for forests and woodlands, agriculture and developed areas, shrublands, and other categories, circa 2000 ............................................... 10

6. Lands managed by the U.S. Department of the Interior ...........................................12

\section{Tables}

1. Biological carbon storage and hypothetical forest biomass carbon sequestration capacity in the conterminous United States.

2. Biological carbon storage and hypothetical forest biomass carbon sequestration capacity on lands managed by the U.S. Department of the Interior in the conterminous United States 


\section{Conversion Factors, Datum, and Abbreviations}

SI to Inch/Pound

\begin{tabular}{lll}
\hline & \multicolumn{1}{c}{ Multiply } & \multicolumn{1}{c}{ To obtain } \\
\hline meter $(\mathrm{m})$ & Length & \\
\hline & 3.281 & foot $(\mathrm{ft})$ \\
\hline square meter $\left(\mathrm{m}^{2}\right)$ & Area & \\
hectare $(\mathrm{ha})$ & 0.0002471 & acre \\
square meter $\left(\mathrm{m}^{2}\right)$ & 2.471 & acre \\
hectare $($ ha) & 10.76 & square foot $\left(\mathrm{ft}^{2}\right)$ \\
& 0.003861 & square mile $\left(\mathrm{mi}^{2}\right)$ \\
\hline gram $(\mathrm{g})$ & Mass & \\
kilogram $(\mathrm{kg})$ & 0.03527 & ounce, avoirdupois $(\mathrm{oz})$ \\
\hline & 2.205 & pound avoirdupois $(\mathrm{lb})$ \\
\hline gram per cubic centimeter $\left(\mathrm{g} / \mathrm{cm}^{3}\right)$ & Density & \\
\hline
\end{tabular}

Horizontal coordinate information is referenced to the North American Datum of 1983 (NAD 83).

LIST OF ABBREVIATIONS

BpS

LANDFIRE Biophysical Setting

$\mathrm{CO}_{2}$

Carbon dioxide

$\mathrm{DOI}$

U.S. Department of the Interior

ESP

LANDFIRE Environmental Site Potential

EVT

LANDFIRE Existing Vegetation Type

FIA

USFS Forest Inventory and Analysis

GIS

Geographic Information System

LANDFIRE

Landscape Fire and Resource Management Planning Tools Project

MODIS

Moderate Resolution Imaging Spectrometer

NBCD

National Biomass and Carbon Dataset

NLCD

National Land Cover Dataset

NRCS

USDA Natural Resources Conservation Service

NVCS

National Vegetation Classification Standard

SClass

LANDFIRE Succession Class

SSURGO

Soil Survey Geographic Database

STATSG02

General Soil Map of the United States

USDA

U.S. Department of Agriculture

USFS

U.S. Forest Service

USGS

U.S. Geological Survey 


\title{
Rapid Assessment of U.S. Forest and Soil Organic Carbon Storage and Forest Biomass Carbon Sequestration Capacity
}

\author{
By Eric T. Sundquist, Katherine V. Ackerman, Norman B. Bliss, Josef M. Kellndorfer, \\ Matt C. Reeves, and Matthew G. Rollins
}

\begin{abstract}
This report provides results of a rapid assessment of biological carbon stocks and forest biomass carbon sequestration capacity in the conterminous United States. Maps available from the U.S. Department of Agriculture are used to calculate estimates of current organic carbon storage in soils (73 petagrams of carbon, or $\mathrm{PgC}$ ) and forest biomass (17 $\mathrm{PgC}$ ). Of these totals, $3.5 \mathrm{PgC}$ of soil organic carbon and $0.8 \mathrm{PgC}$ of forest biomass carbon occur on lands managed by the U.S. Department of the Interior (DOI). Maps of potential vegetation are used to estimate hypothetical forest biomass carbon sequestration capacities that are 3-7 PgC higher than current forest biomass carbon storage in the conterminous United States. Most of the estimated hypothetical additional forest biomass carbon sequestration capacity is accrued in areas currently occupied by agriculture and development. Hypothetical forest biomass carbon sequestration capacities calculated for existing forests and woodlands are within $\pm 1 \mathrm{PgC}$ of estimated current forest biomass carbon storage. Hypothetical forest biomass sequestration capacities on lands managed by the DOI in the conterminous United States are 0-0.4 PgC higher than existing forest biomass carbon storage. Implications for forest and other land management practices are not considered in this report. Uncertainties in the values reported here are large and difficult to quantify, particularly for hypothetical carbon sequestration capacities. Nevertheless, this rapid assessment helps to frame policy and management discussion by providing estimates that can be compared to amounts necessary to reduce predicted future atmospheric carbon dioxide levels.
\end{abstract}




\section{Introduction}

This report by the U.S. Geological Survey (USGS) provides the results of a rapid assessment of biological carbon stocks and biological carbon sequestration capacity in the conterminous United States. The rapid assessment, which includes estimates of storage and capacity for lands managed by the U.S. Department of the Interior (DOI), was requested by the DOI to provide timely and objective scientific information in support of the DOI's stewardship of land and natural resources. Assessment of nationwide biological carbon storage and carbon sequestration capacity is needed to determine effective ways to help reduce rising carbon dioxide $\left(\mathrm{CO}_{2}\right)$ levels in the atmosphere. This rapid assessment also points toward the need for more data and knowledge to inform management and policy decisions.

Estimates of the amount of present-day biological carbon storage are important because they quantify a baseline for assessing potential future carbon storage gains or losses. Estimates of carbon sequestration capacity, or the total amount of carbon that might be stored under idealized conditions, are important because they can be used to quantify potential longterm contributions to reducing the rise in atmospheric $\mathrm{CO}_{2}$ levels. These estimates provide fundamental information needed to frame and inform national and international public discussion of the broad range of options for carbon management.

This rapid assessment provides national estimates, including estimates for DOI lands, of (1) existing biological carbon storage on land, aboveground and belowground; and

(2) hypothetical forest biomass carbon sequestration capacity on land, based on estimates of biomass in potential vegetation. Maps of existing and potential vegetation are used to calculate carbon storage and hypothetical capacity. Hypothetical amounts of additional biomass carbon sequestration can be inferred from differences between estimates of carbon stored in existing vegetation and in potential vegetation.

Comparisons of existing vegetation to historical and potential vegetation have long been used to estimate effects of human land management on terrestrial carbon storage. Houghton and coworkers pioneered the calculation of timedependent effects of land-use change on historical carbon storage in soils and vegetation (Houghton and others, 1983). Houghton's method was used to estimate a net loss of approximately 33 petagrams of carbon $(\mathrm{PgC})$ from U.S. forests and soils between 1700 and 1990 (Houghton and Hackler, 2000). By comparing maps of natural vegetation (that is, vegetation prior to human disturbance) to a map of existing vegetation, DeFries and others (1999) inferred a net loss of approximately 26-27 PgC from North American vegetation and soils that was due to land use prior to 1987. Estimates of historical depletion of biological carbon storage are widely utilized in estimates of future carbon sequestration capacity (for example, House and others, 2002; Ruddiman, 2007; Canadell and Raupach, 2008; Rhemtulla and others, 2009; Pongratz and others, 2009).
The results of the rapid assessment described in this report should be viewed as a research product rather than as a comprehensive resource assessment. Because maps of potential vegetation are inherently idealized or hypothetical, carbon sequestration capacities that are calculated from these maps must be regarded as hypothetical. Because the biomass calculations documented in this report are derived from a map that depicts only the distribution of forest biomass, nonforest biomass is not considered. This assessment is intended to provide timely and reproducible analysis based on available information and is limited to approximations based on published datasets and idealized assumptions. The work described here is not intended to replace more detailed ongoing assessment activities such as those of the U.S. Forest Service (USFS), the U.S. Environmental Protection Agency (USEPA), and the USGS.

\section{Data and Methods}

The estimates in this report are derived from previously published datasets that characterize soil, vegetation, and potential vegetation within the conterminous United States. Organic carbon storage in soils is calculated from the Soil Survey Geographic (SSURGO) database developed by the U.S. Department of Agriculture (USDA) Natural Resources Conservation Service (NRCS). Carbon storage in forest biomass is derived from the published database developed by the USDA Forest Service by Blackard and coworkers (Blackard and others, 2008). Forest biomass carbon sequestration capacity is estimated by merging the USFS forest biomass database with maps of existing and potential vegetation distribution from the Landscape Fire and Resource Management Planning Tools Project (LANDFIRE) (Rollins, 2009).

\section{Soil Organic Carbon}

Estimates of organic carbon storage in existing soils are calculated from soil properties compiled in the SSURGO database. SSURGO data are available to the public through the NRCS Soil Data Mart Web site (http://soildatamart. nrcs.usda.gov/). We use the geodatabase file "2009_q2_ nat_ssurgo_fgdb $\backslash$ SDM_Export.gdb," which provides data that were updated during the second quarter of 2009. The SSURGO data are compiled at 1:24,000 map scale and are available for approximately 85 percent of the land area of the conterminous United States. Where SSURGO data are not available, estimates are supplemented by using data from the General Soil Map of the United States (also known as STATSGO2; http://soils.usda.gov/survey/geography/statsgo/). The STATSGO2 database is compiled at 1:250,000 map scale using a structure and methods similar to the SSURGO database. Soil data in the SSURGO and STATSGO2 databases were collected over a period of many years and thus represent generalized recent conditions. 
Methods for calculating soil organic carbon storage are well established from previously published USGS estimates of soil carbon in the United States and DOI lands based on the STATSGO database (Bliss, 2003). The SSURGO and STATSGO2 databases define multiple soil layers, or horizons, to represent changes in soil properties as a function of depth below the surface. The databases include, for each soil horizon, measures of depth, texture, particle-size distribution, bulk density, and organic matter. These records are a generalized representation of the soil-horizon information obtained in laboratory analysis of field samples. From these data, the mass of organic matter per unit of surface area is computed for each soil horizon. The values for organic matter are converted to a measure of soil organic carbon by multiplying by 0.58 (Natural Resources Conservation Service, 2004, p. 347). Bedrock layers and rock fragments are excluded from the soil organic carbon analysis. Soil organic carbon values calculated for individual soil horizons are totaled to yield the soil organic carbon storage per unit area over the total soil profile, which is defined as all horizons present in the database.

SSURGO and STATSGO2 are relational databases that can be used to aggregate estimates of soil organic carbon storage from individual horizons and profiles to spatial soil units identified as soil components and map units. Soil components represent soil classification series that are not explicitly mapped but nevertheless distinguish important variations of soil characteristics that occur within soil map units. Soil map units can be displayed explicitly in maps. Percentages are specified in the databases to specify the relative areas of the components within each soil map unit. Estimates for individual horizons are combined to provide estimates for the total soil profile in each soil component. Component soil organic carbon values are then used to compute area-weighted averages based on the percentages specified in the databases to represent relative areas of the components within each map unit. If the sum of the component area percentages is less than 100 but greater than or equal to 55 percent, then the properties of the reported soils are extended to the apparently unreported soil area. If the sum of the component area percentages is less than 55 percent, then the map unit is recorded as "No Data" for SSURGO, and information is substituted from STATSGO2. Map units or components are given a soil organic carbon value of zero if they represent nonsoil (such as water, gravel pit, rock outcrop, and urban land). The map unit soil organic carbon averages are expressed as carbon intensity, in kilograms of carbon per square meter. These carbon intensities are mapped at 300-meter (m) resolution. Gaps in the SSURGO database are filled by using carbon intensities calculated from the STATSGO2 database. The carbon intensities are multiplied by map-unit areas to get estimates of total soil organic carbon storage.

\section{Biomass and Carbon in Existing Forest Vegetation}

Estimates of biomass and carbon in existing forest vegetation are derived from the USFS database of Blackard and others (2008). This database provides maps of forest/ nonforest distribution, forest biomass, and forest biomass error at 250-m resolution for the conterminous United States, Alaska, and Puerto Rico. The dataset is based on groundmeasured plot data from the USFS Forest Inventory and Analysis (FIA) program. These data are linked as response variables to empirical models of geospatial predictor variables including data from the Moderate Resolution Imaging Spectrometer (MODIS; Justice and others, 2002), the USGS National Land Cover Dataset 2001 (NLCD92) (Vogelmann and others, 2001), and data representing climate and topography. The models are optimized by mathematical regression and classification methods and tested by using ground-measured data from randomly selected FIA plots that were withheld from the optimization process. Further details are described by Blackard and others (2008).

The USFS forest biomass dataset adheres as much as possible to the FIA definitions (prior to 2009) of forest land as requiring an area of at least 0.405 hectare (ha), a minimum continuous canopy width of $36.58 \mathrm{~m}$ with approximately 5-10 percent cover by live trees (depending on forest type), and an understory that is undisturbed by nonforest land use such as residences and agriculture (Smith and others, 2009). Areas that do not meet these criteria are classified as "nonforest" and no forest biomass is assigned. Because of this definition, our assessment does not include estimates of biomass carbon storage or sequestration capacity for nonforest areas, including shrublands and some woodlands.

The USFS forest biomass dataset of Blackard and others (2008) includes measures of model performance and uncertainty. Maps of uncertainty measures are available for forest/nonforest classification and forest biomass. These maps indicate important regional variations of systematic bias. For example, although State-level total biomass estimates are within 10 percent of plot-based estimates in 21 States, Statelevel biomass estimates are significantly underestimated in California, Oregon, and Washington; and State-level biomass estimates are significantly overestimated in Alaska, Florida, Georgia, North Carolina, Oklahoma, Virginia, and West Virginia. These variations reflect an overall tendency for the modeled biomass to be overpredicted in areas of relatively small biomass and underpredicted in areas of relatively large biomass.

Following the approach of Blackard and others (2008), we estimate belowground biomass (roots) as 25 percent of aboveground predicted biomass (live trees, stumps, branches, and twigs) (Cairns and others, 1997), and we calculate biomass carbon as 50 percent of dry biomass (Houghton and Hackler, 2000). 


\section{Biomass and Carbon in Potential Vegetation}

\section{The LANDFIRE Dataset}

The LANDFIRE database provides maps at 30-m resolution of existing and potential vegetation, surface canopy and fuel characteristics, historical fire regimes, and other information used in wildland fire management programs. The rapid assessment described in this report uses well-documented LANDFIRE national maps that represent the geospatial distribution of existing vegetation, potential vegetation, and successional stage.

The LANDFIRE map of existing vegetation type (EVT) represents the geospatial distribution of vegetation type and structure around the year 2000. Georeferenced field data are used to assign field plots to map units that are based on the NatureServe Ecological Systems classification (Comer and others, 2003). These field data and classifications are then integrated with Landsat imagery and biophysical datasets to create wall-to-wall maps of existing vegetation type, canopy cover, and canopy height.

Potential vegetation is a long-established ecological concept, defined as the stable vegetation community that would occur as a result of ecological succession under certain specified historical and (or) biophysical conditions (Küchler, 1964; Daubenmire, 1968; and Pfister and Arno, 1980). The LANDFIRE program provides two national potential vegetation maps. One map (called Environmental Site Potential, or ESP) represents the distribution of vegetation that could be supported at a given site based on the biophysical environment in the absence of disturbance. The other map (termed Biophysical Setting, or BpS) indicates the distribution of vegetation in the presence of expected historical disturbances (such as fire, insects, disease, native grazing, and weather stress) prior to Euro-American settlement. These maps are combined with other spatial information and with dynamic vegetation models to develop maps of historical fire regimes, as well as current characteristics of fire fuels and vegetation.

The LANDFIRE Succession Class (SClass) map represents the current successional states of vegetation as determined by combining LANDFIRE maps of existing vegetation (vegetation type, cover, and height) with the defined successional vegetation cover and height rules outlined in nationally consistent and locally reviewed dynamic vegetation models for each BpS map unit (Holsinger and others 2006). Using a common modeling framework (the Vegetation Dynamics Development Tool), several hundred regional ecologists and fire managers participated in multiple regional workshops to develop more than 1,000 vegetation models representing ecosystems throughout the conterminous United States. Model development was refined by extensive internal and external review. The resulting LANDFIRE succession classes categorize current vegetation composition and structure in as many as five successional states for each $\mathrm{BpS}$ vegetation map unit. Each BpS map unit is associated with a set of historical reference conditions expressed as area percentages of each succession class, derived by using the LANDSUM landscape simulation system. Further details describing the LANDFIRE maps and procedures are available on the Web at http://www. landfire.gov/.

\section{Potential Forest Vegetation Biomass and Carbon}

We determine a range of hypothetical carbon sequestration capacities by linking the LANDFIRE potential vegetation datasets to the USFS estimates of existing forest biomass by Blackard and others (2008). Hypothetical distributions of vegetation types and succession classes from the LANDFIRE potential vegetation maps (ESP and BpS) are linked to corresponding biomass estimates derived from the distribution of biomass in existing vegetation. Two measures of hypothetical carbon sequestration capacity are derived based on the two LANDFIRE potential vegetation datasets. These measures are:

1. Hypothetical undisturbed forest biomass carbon sequestration capacity, defined as an estimate of carbon storage attributed to the distribution of ESP vegetation map units. Each ESP map unit is assigned a biomass determined from measurements of existing forest biomass in the highest (or latest) succession class of a corresponding existing vegetation type. This hypothetical capacity thus reflects an estimate of hypothetical undisturbed vegetation distribution combined with measurements of biomass in minimally disturbed (late-succession) existing forests.

2. Hypothetical historical forest biomass carbon sequestration capacity, defined as an estimate of carbon storage attributed to the distribution of $\mathrm{BpS}$ vegetation map units. Each BpS map unit is assigned a biomass determined from measurements of existing forest biomass across the range of succession classes for a corresponding existing vegetation type. The proportional distribution of succession classes for each vegetation type is taken from modeled reference conditions specified for each BpS unit. This hypothetical capacity thus represents an estimate of hypothetical pre-Euro-American distribution of vegetation types and successional stages combined with measurements of biomass in corresponding existing vegetation units.

By using straightforward geographic information system (GIS) techniques, USFS forest biomass and carbon values are merged with LANDFIRE EVT and SClass maps. Statistical metrics of biomass and carbon are determined for each SClass within each EVT vegetation type. Because LANDFIRE maps of existing and potential vegetation (EVT, ESP, and BpS) use identical vegetation classifications, the statistical analysis of existing biomass and carbon in EVT and SClass map units can be transferred to ESP and BpS map units according to vegetation type and appropriate succession stage. 
The methods of analysis can be summarized as follows:

1. LANDFIRE EVT and SClass maps are combined to yield a map of succession class distributions for each existing vegetation type.

2. Zonal statistics of USFS forest biomass values are determined for each succession class within each EVT vegetation type. This analysis provides the basis for extending the observed relationships to maps of potential vegetation.

3. Late-succession SClass values of biomass and carbon are applied to ESP map units. The resulting map represents hypothetical undisturbed forest biomass carbon sequestration capacity.

4. BpS historical reference conditions (expressed as percentages of SClass areas by map unit) are used to determine values of biomass and carbon for $\mathrm{BpS}$ map units. The resulting map represents hypothetical historical forest biomass carbon sequestration capacity.

To be consistent with our estimates of carbon storage in existing vegetation, we estimate belowground biomass (roots) in potential vegetation as 25 percent of aboveground biomass (live trees, stumps, branches, and twigs) (Cairns and others, 1997), and we calculate carbon in potential vegetation as 50 percent of dry biomass (Houghton and Hackler, 2000).

\section{Land Cover and Land Use}

Any assessment of hypothetical biological carbon sequestration capacity must consider the relations between capacity estimates and existing land cover and land use. To be consistent with our application of the LANDFIRE dataset, we use general categories of land cover and land use taken from the LANDFIRE EVT map and data fields. These categories were extracted by the LANDFIRE program from the USGS National Land Cover Dataset 2001 (NLCD 2001) (Homer and others, 2004). We approximate the distribution of forests and woodlands to correspond to the "Tree-dominated" National Vegetation Classification System (NVCS) Order in the EVT dataset. We approximate the distribution of shrublands to correspond to the NVCS Order "Shrub-dominated" in the EVT dataset. We approximate the distribution of agricultural and developed land use to correspond to System Group ID codes 20-24 and 80-84 in the EVT dataset. Remaining areas are assumed to be grasslands and other herbaceous areas, nonvegetated areas, and open water. Estimates of carbon storage and hypothetical carbon sequestration capacity for these land cover/use categories are derived by using the selected EVT coverages as GIS masks to extract values from the corresponding datasets.

\section{Lands Managed by the U.S. Department of the Interior}

Polygons representing lands managed or administered by the U.S. Government are available online from the U.S. National Atlas at http://dds.cr.usgs.gov/pub/data/nationalatlas/fedlanp020.tar.gz. These polygons were projected and sorted by attribute to yield polygons of lands managed by the bureaus of the DOI (Bureau of Land Management, Bureau of Reclamation, Fish and Wildlife Service, and National Park Service). Estimates of carbon storage and hypothetical carbon sequestration capacity for DOI lands are derived by using the DOI bureau polygons as GIS masks to extract values from the corresponding datasets. For the rapid assessment, estimates are given for aggregate DOI lands only. Individual bureau estimates are not itemized.

\section{Results and Discussion}

Maps of existing soil organic carbon and existing forest biomass carbon in the conterminous United States are shown in figures 1 and 2, respectively. The estimated total soil organic carbon storage is $73 \mathrm{PgC}$ (billion metric tons), and the estimated total forest biomass carbon is $17 \mathrm{PgC}$ (table 1). Highest regional densities of soil organic carbon storage occur in the agricultural soils of the north-central Midwest, and highest densities of forest biomass carbon storage occur in the conifer forests of the Pacific Northwest.

A map of hypothetical undisturbed forest biomass carbon sequestration capacities is shown in figure 3 , and a map of hypothetical historical forest biomass carbon sequestration capacities is shown in figure 4. Estimated capacity totals calculated from these maps are approximately 24 (undisturbed) and $20 \mathrm{PgC}$ (historical) (table 1). These totals are 7 and $3 \mathrm{PgC}$ greater than the estimated existing forest biomass carbon storage shown in figure 2. Comparison of figures 3 and 4 to figure 2 shows that hypothetical increases in forest biomass carbon storage are apparent in every region of the country. As expected, estimates of forest biomass carbon sequestration capacities are greater under hypothetical undisturbed conditions (fig. 3) than under hypothetical historical conditions (fig. 4).

Interpretation of figures 1-4 requires knowledge of existing land cover and land use. The circa 2000 distribution of forests and woodlands, agriculture and developed areas, shrublands, and other categories are shown in figure 5. This map is used to extract totals from figures 1-4 to show the distribution of biological carbon storage and hypothetical forest biomass carbon sequestration capacities in relation to existing land cover and land use (table 1).

As shown in table 1, most of the differences between hypothetical forest biomass carbon sequestration capacities 


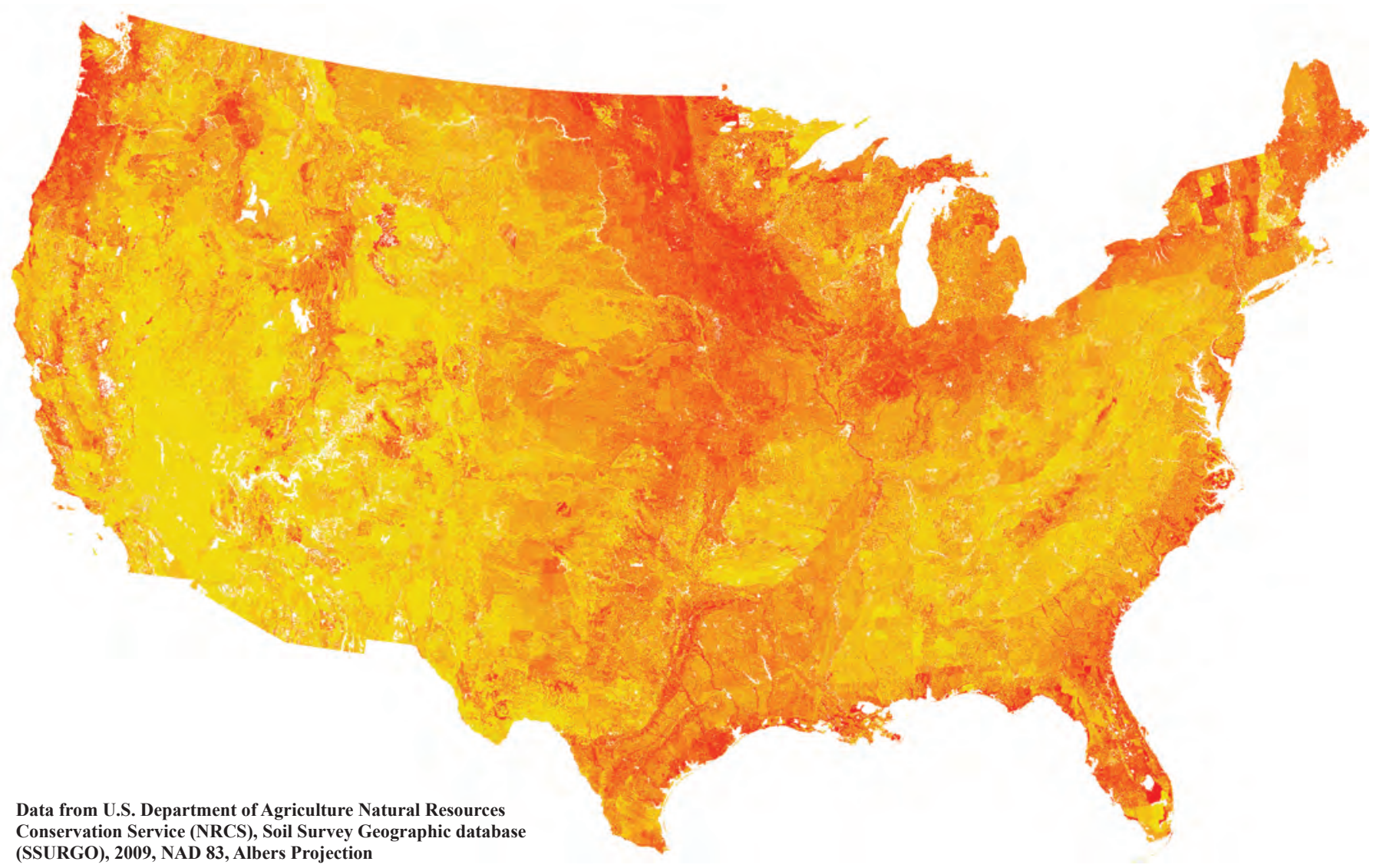

\section{EXPLANATION}

Total soil organic carbon, in kilograms per square meter

\begin{tabular}{|lllllll|}
\hline & & & & & & \\
\hline 0 & 5 & 10 & 15 & 20 & 60 & $>100$
\end{tabular}

Figure 1. Existing soil organic carbon, based on the SSURGO and STATGSO2 databases. Values shown represent the total soil profile. 


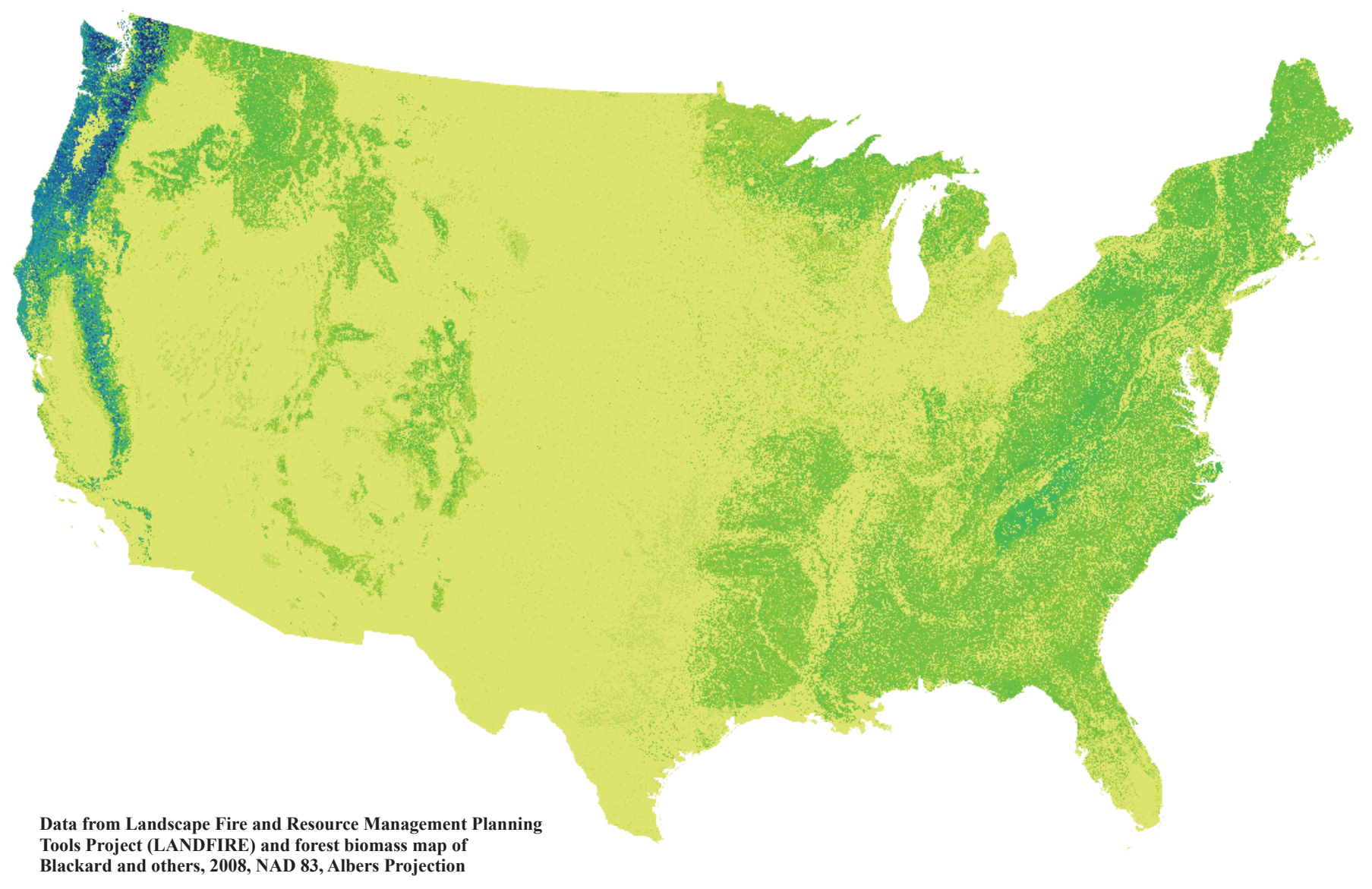

EXPLANATION

Total biomass carbon, in kilograms per square meter

\begin{tabular}{|lllll|}
\hline & & & & \\
\hline 0 & 5 & 10 & 15 & $>20$
\end{tabular}

Figure 2. Existing forest biomass carbon, based on the USFS forest biomass map by Blackard and others (2008). 


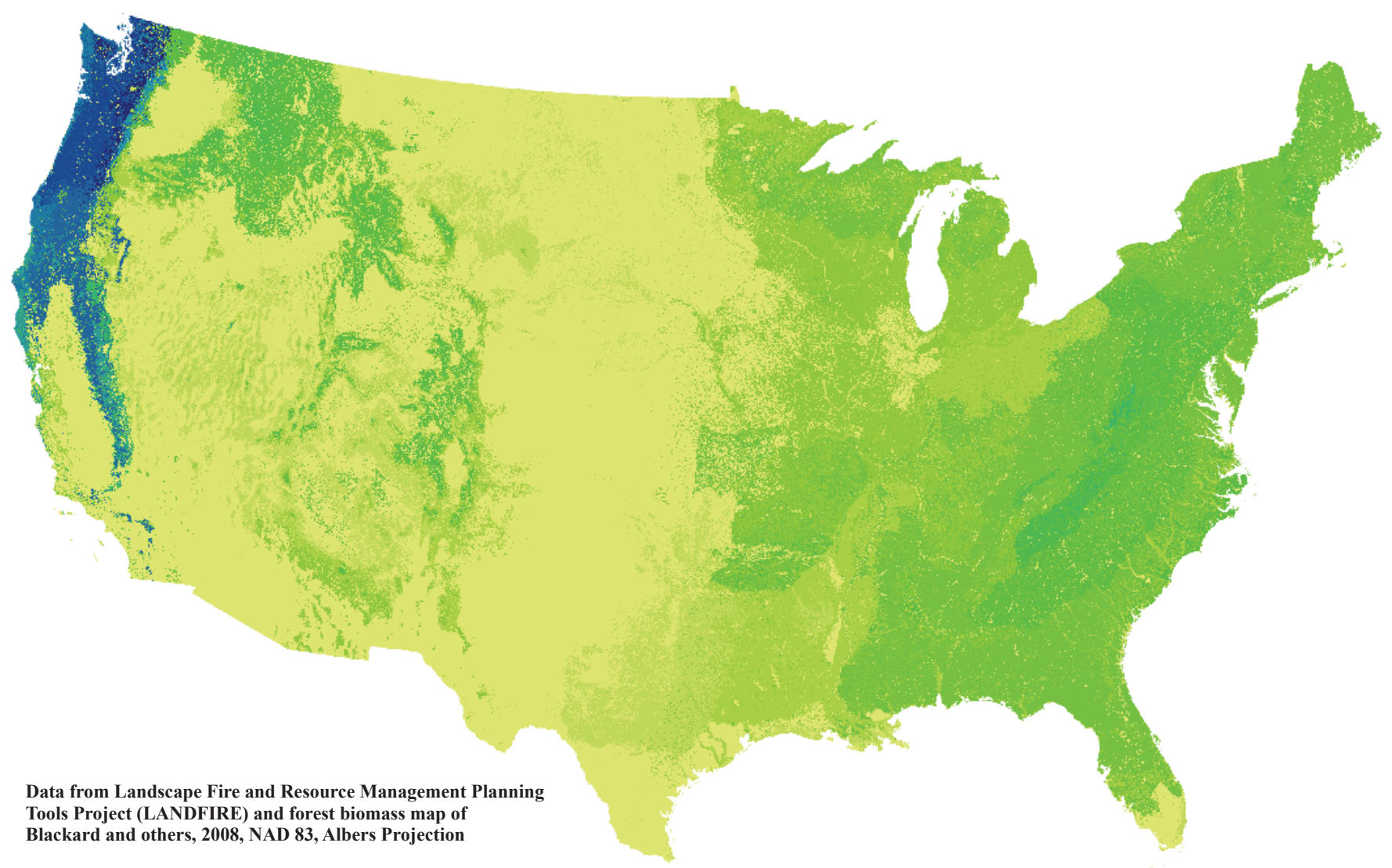

\section{EXPLANATION}

Total biomass carbon, in kilograms per square meter

\begin{tabular}{|lllll|}
\hline & & & & \\
\hline 0 & 5 & 10 & 15 & $>20$
\end{tabular}

Figure 3. Hypothetical undisturbed forest biomass carbon sequestration capacity. 


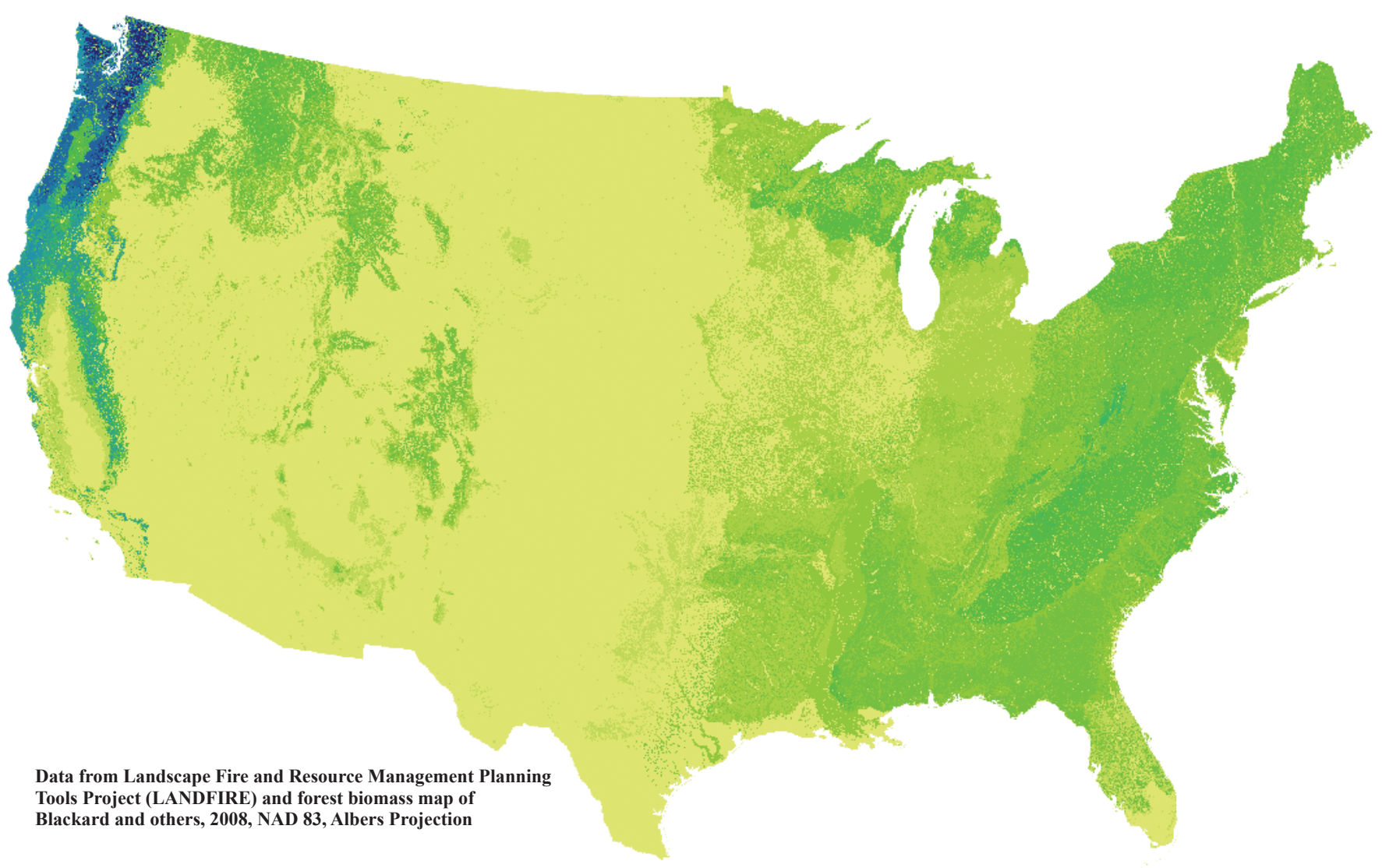

\section{EXPLANATION}

Total biomass carbon, in kilograms per square meter

\begin{tabular}{|lllll|}
\hline & & & & \\
\hline 0 & 5 & 10 & 15 & $>20$
\end{tabular}

Figure 4. Hypothetical historical forest biomass carbon sequestration capacity. 


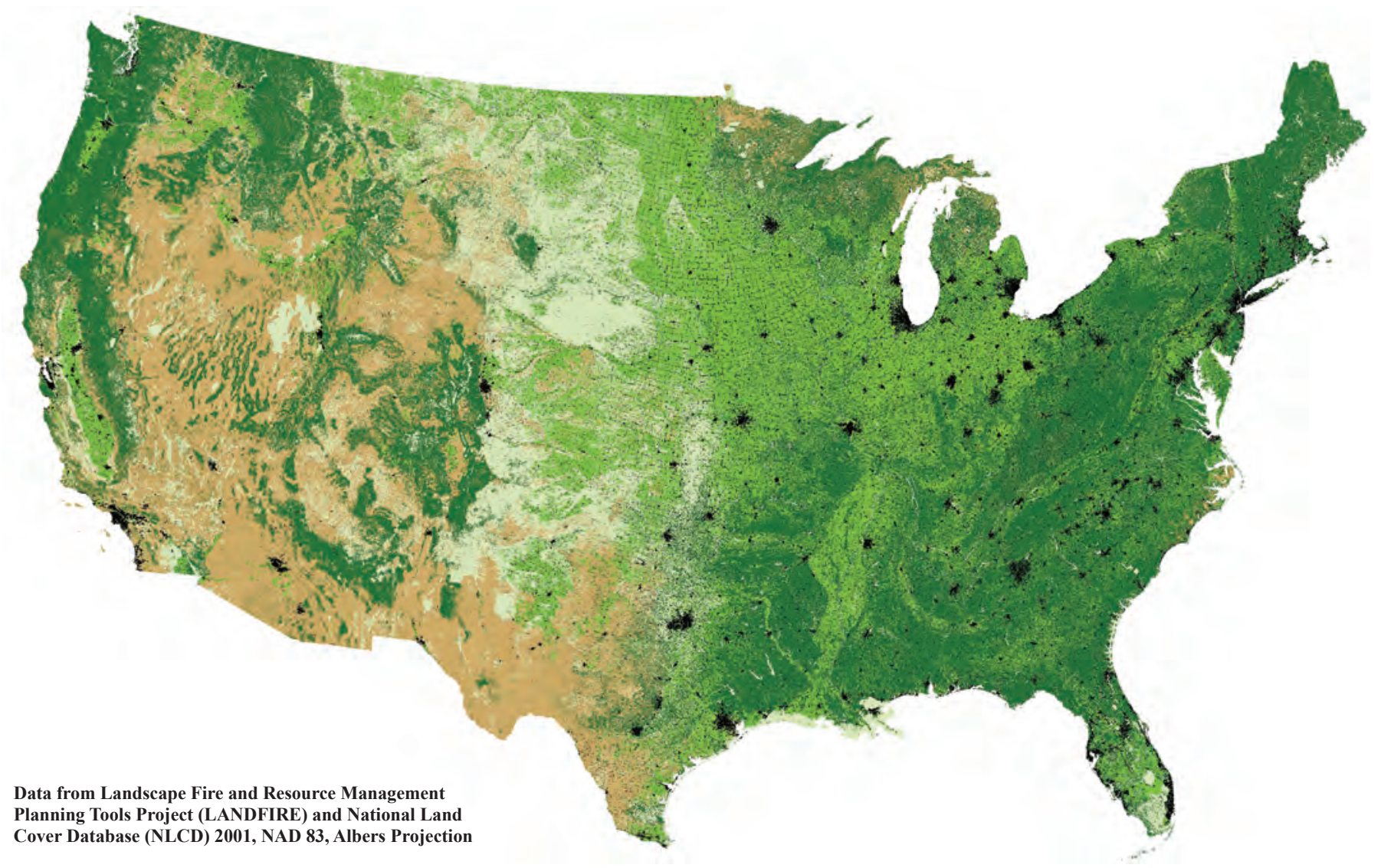

\section{EXPLANATION}

Land use categories

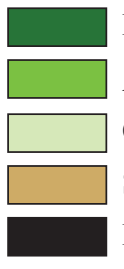

Forest/woodland

Agriculture

Other (for example, grassland)

Shrubland

Developed

Figure 5. Land cover and land use for forests and woodlands, agriculture and developed areas, shrublands, and other categories, circa 2000. Data are from LANDFIRE and NLCD 2001. 
Table 1. Biological carbon storage and hypothetical forest biomass carbon sequestration capacity in the conterminous United States.

[Parentheses show areas in million hectares. NVCS, National Vegetation Classification System; LANDFIRE, Landscape Fire and Resource Management Planning Tools Project; EVT, existing vegetation type]

\begin{tabular}{|c|c|c|c|c|}
\hline Existing land cover & $\begin{array}{l}\text { Existing soil } \\
\text { organic carbon }\end{array}$ & $\begin{array}{l}\text { Existing forest } \\
\text { biomass carbon }\end{array}$ & $\begin{array}{l}\text { Hypothetical undisturbed } \\
\text { forest biomass carbon } \\
\text { sequestration capacity }\end{array}$ & $\begin{array}{l}\text { Hypothetical historical } \\
\text { forest biomass carbon } \\
\text { sequestration capacity }\end{array}$ \\
\hline & \multicolumn{4}{|c|}{ All values are in petagrams of carbon } \\
\hline Forests and woodlands ${ }^{1}(266)$ & 25.13 & 14.28 & 15.05 & 13.27 \\
\hline Agriculture and developed ${ }^{2}(221)$ & 27.42 & 1.40 & 5.89 & 4.74 \\
\hline Shrublands ${ }^{3}$ (159) & 9.67 & 0.67 & 1.63 & 0.93 \\
\hline Other $^{4}(165)$ & 11.20 & 0.66 & 1.37 & 0.88 \\
\hline Totals (811) & 73.40 & 17.02 & 23.94 & 19.82 \\
\hline
\end{tabular}

and existing forest biomass carbon storage are accrued in areas that are now occupied by agriculture and other forms of land development. This difference is of particular importance in determining practical potential for additional forest biomass carbon sequestration. Although agricultural soils are known to be capable of additional carbon sequestration (not estimated in this assessment), expansion of forest biomass in these areas would require changes in land use. In areas now occupied by forests and woodlands, differences between existing forest biomass carbon storage and hypothetical forest biomass carbon sequestration capacities are much smaller. Under our hypothetical undisturbed conditions, additional forest biomass carbon sequestration capacity is less than $1 \mathrm{PgC}$ in existing forests and woodlands. Under our hypothetical historical conditions, forest biomass carbon sequestration capacity is $1 \mathrm{PgC}$ less than current storage in existing forests and woodlands. These differences between hypothetical and existing forest biomass totals are probably within the range of uncertainties in our assessment.

Lands managed by the U.S. Department of the Interior are shown in figure 6. Existing biological carbon storage and hypothetical forest biomass carbon sequestration capacities for these lands are shown in table 2. This table also shows a comparison to recent preliminary estimates of existing forest biomass carbon provided by the USFS FIA program (Linda Heath, U.S. Forest Service, written commun., 2009). The comparison with FIA biomass carbon data shows close agreement. The relationships between existing forest biomass carbon storage and hypothetical sequestration capacities are similar to those observed for existing forest areas shown in table 1.

\section{Limitations of this Assessment}

Uncertainties in this assessment are significant and difficult to estimate. Sources of uncertainty include field sampling and measurements, spatial extrapolations based on remotely sensed data, and differences in definitions and assumptions among the variety of datasets used. For example, the USFS forest biomass dataset used in this assessment is based on FIA definitions of forest land, whereas the LANDFIRE ecosystem classification system used in the assessment does not follow the FIA criteria to distinguish "forest" and "nonforest" categories. When these datasets are combined as in this rapid assessment, errors are introduced by inherent classification differences. Effects of these errors on overall uncertainties need to be more rigorously quantified in future work.

Uncertainties in hypothetical estimates of sequestration capacity are particularly problematic. By comparing our results with previously published results, (Bliss, 2003; Blackard and others, 2008), we estimate provisionally that our totals of soil organic carbon storage are accurate to within \pm 30 percent, our totals of forest biomass carbon storage are accurate to within \pm 20 percent, and our totals of hypothetical forest biomass carbon sequestration capacities are accurate to within \pm 30 percent given the underlying hypothetical assumptions. Given these uncertainties, inferred differences between our calculated totals are obviously subject to large relative uncertainties. Nevertheless, we believe that the results shown in figures 1-4 and tables 1 and 2 represent an important first 


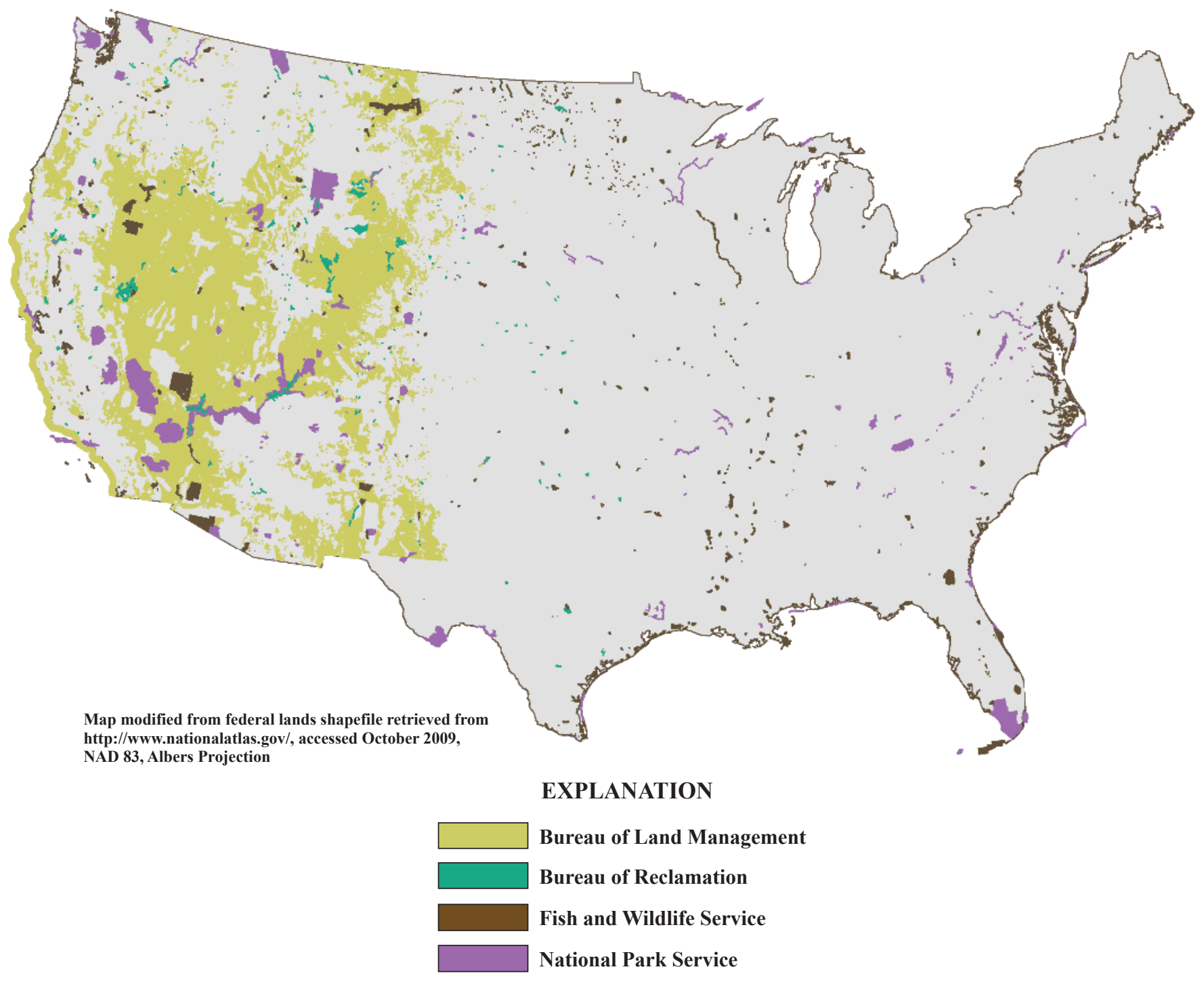

Figure 6. Lands managed by the U.S. Department of the Interior. 
Table 2. Biological carbon storage and hypothetical forest biomass carbon sequestration capacity on lands managed by the U.S. Department of the Interior in the conterminous United States.

[Parentheses show areas in million hectares. FIA, U.S. Forest Service Forest Inventory and Analysis]

\begin{tabular}{ccccc}
\hline $\begin{array}{c}\text { Existing soil organic } \\
\text { carbon }\end{array}$ & $\begin{array}{c}\text { Existing forest biomass } \\
\text { carbon, FIA }{ }^{1,2}\end{array}$ & $\begin{array}{c}\text { Existing forest biomass } \\
\text { carbon, this study }\end{array}$ & $\begin{array}{c}\text { Hypothetical undisturbed } \\
\text { forest biomass carbon } \\
\text { sequestration capacity }\end{array}$ & $\begin{array}{c}\text { Hypothetical historical } \\
\text { forest biomass carbon } \\
\text { sequestration capacity }\end{array}$ \\
\hline \multicolumn{5}{c}{ All values are in petagrams of carbon } \\
\hline 3.48 & ${ }^{3} 0.95(17.2)$ & ${ }^{3} 0.81(91.6)$ & 1.24 & 0.84 \\
\hline
\end{tabular}

${ }^{1}$ FIA plot-based data are for 2003-05 depending on regional inventory schedule. These preliminary estimates are provided by Linda Heath (U.S. Forest Service, written commun., 2009), based on data from U.S. Forest Service (2009), and methods used for the official greenhouse gas inventories (U.S. Department of Agriculture, 2008).

${ }^{2}$ FIA plot-based estimates not immediately available for the Bureau of Reclamation.

${ }^{3}$ Area for existing forest biomass carbon, FIA, is forest area only, using FIA forest-classification criteria. Area for existing forest biomass carbon, this study, is total area of forest and nonforest lands.

step toward assessment of biological carbon sequestration capacities in the United States.

This rapid assessment is limited to direct calculations from existing datasets, supplemented by simple extrapolations and inferences taken from the scientific literature. Estimates for Alaska and Hawaii are not calculated because of the relatively limited data coverage in these States. Nonforest biomass is excluded because the USFS dataset of Blackard and others (2008) is restricted to forest biomass as defined for the FIA. Biomass carbon storage and sequestration capacities are not estimated for shrublands and other nonforest areas. The contribution of shrublands to estimates of hypothetical carbon sequestration capacity is not considered in this report.

Because of the complexities and large uncertainties apparent in the scientific literature concerning potential soil carbon sequestration, especially in forested lands, the rapid assessment does not include estimates of soil carbon sequestration capacity. Similarly, although our determinations of soil organic carbon include wetland soils, we have not estimated carbon storage in aquatic sediments or carbon sequestration capacity that might occur through wetland restoration or management of water impoundments. We have also omitted estimates of current carbon storage and sequestration capacity in forest accumulations of dead woody debris.

Throughout this report, we emphasize that our estimates of forest biomass carbon sequestration capacities are based on assumptions of hypothetical disturbance conditions derived from the LANDFIRE ESP and BpS maps. The ESP map is, by definition, a strictly hypothetical distribution based on the unrealistic assumption of no disturbance. The BpS map represents historical (pre-Euro-American settlement) conditions, but BpS map units may not represent vegetation that can be expected to occur on the landscape under current or future conditions. For example, thresholds may have been crossed in the introduction of invasive plant species, soil modification, hydrologic engineering, urban development, forest management, wildland fire suppression, and other practices that would make recurrence of historical conditions unrealistic. Changing climatic conditions may affect the current and future distribution of vegetation types, and may induce more transient conditions than those represented by the BpS and ESP maps. Because they represent hypothetical disturbance conditions, the BpS and ESP maps cannot be subjected to quantitative validation or error analysis. These limitations are an important source of uncertainty in the results of the rapid assessment.

The results of this assessment require cautious interpretation when applied to specific programs or projects. The calculated additions may not account for realistic effects of future changes in climate, land use, and availability of water and nutrients. Attaining historical or undisturbed sequestration capacities will also be constrained by costs and tradeoffs with respect to other resources, particularly agriculture. Generalized capacity estimates that may be useful for large areas (such as continents or nations) may be inapplicable at more local scales. Similarly, capacity estimates may be useful in evaluating long-term policies for coming decades, but may not provide any information about time-dependent sequestration rates in the more immediate future.

\section{Implications of this Assessment}

Implications of this rapid assessment for policy and management are beyond the scope of this report. However, the assessment helps to frame policy and management discussions by providing information about existing biological carbon 
storage and about biological carbon sequestration capacity. Differences between existing carbon storage and hypothetical historical or undisturbed carbon sequestration capacity represent a range of possible values for additional carbon sequestration. These values can be compared to amounts necessary to reduce predicted future atmospheric $\mathrm{CO}_{2}$ levels.

Further work is needed to establish whether the results of this assessment are robust upper limits for additional biological carbon sequestration. Although the hypothetical historical and undisturbed conditions considered in this report might define scenarios for high amounts of forest carbon storage, the calculated forest biomass carbon sequestration capacities do not include factors that might lead to higher values. For example, future plant growth may be enhanced by $\mathrm{CO}_{2}$ fertilization or nitrogen deposition, and carbon storage may be increased by accumulation of coarse woody debris in mature forests. Calculated sequestration capacities might be revised upward if higher biomass estimates are assigned on the basis of potential growth curves rather than the existing vegetation succession classes used in this assessment. On the other hand, consideration of other factors may cause sequestration capacities to be revised downward. In particular, effects of future changes in climate and land use may limit or decrease carbon storage in terrestrial ecosystems.

Improved assessment of biological carbon sequestration capacity will require understanding ecosystem processes and management options at more local scales than the maps used in this assessment. The approach described in this report can be extended to more detailed consideration of regional differences and sources of error, but the national databases used in this assessment are inherently limited in their applicability at local scales. More detailed regional and local information will be essential to refining assessments of biological carbon sequestration capacity.

Scientists and resource managers within the U.S. Department of the Interior are working together to identify priority ecosystems and areas where opportunities for enhanced biological carbon sequestration can be pursued, and where challenges for sustaining current levels of carbon storage need to be addressed. Scientific understanding of biological carbon storage requires broad interdisciplinary expertise, and management of biological carbon storage requires recognition that carbon cannot be managed in isolation from other resources. Effective collaboration between scientists and resource managers requires ongoing consideration of a broad range of scientific issues and management options.

This rapid assessment is a first step toward comprehensive assessment of biological carbon sequestration resources in the United States. Improved estimates of potential sequestration capacities and rates will depend ultimately on advances in understanding the changing environmental and human factors that affect biological carbon storage.

\section{Acknowledgments}

We are grateful to David Hayes (U.S. Department of the Interior) and Kit Batten (U.S. Department of the Interior) for challenging us to provide a timely assessment based on the best available information. We thank Greg Dillon (U.S. Forest Service), James Smith (The Nature Conservancy), and Zhiliang Zhu (U.S. Geological Survey) for sharing their knowledge of the LANDFIRE dataset. We thank Linda Heath (U.S. Forest Service) for sharing her FIA calculations and insights. Gretchen Moisen (U.S. Forest Service) helped us to access and understand the USFS forest biomass dataset. Valuable review comments were provided by Linda Heath (U.S. Forest Service), David McGuire (U.S. Geological Survey, University of Alaska), Steven Perakis (U.S. Geological Survey), and Mark Waldrop (U.S. Geological Survey). Bill Werkheiser (U.S. Geological Survey), Debra Foster (U.S. Geological Survey), Christine Mendelsohn (U.S. Geological Survey), Marilyn Billone (U.S. Geological Survey), Beth Vairin (U.S. Geological Survey), Ann Marie Squillacci (U.S. Geological Survey), and Sandra Cooper (U.S. Geological Survey) guided us through the publication process in record time. Support for this study was provided by the USGS National Research Program and the USGS Global Change Program.

\section{References Cited}

Blackard, J.A., Finco, M.V., Helmer, E.H., Holden, G.R., Hoppus, M.L., Jacobs, D.M., Lister, A.J., Moisen, G.G., Nelson, M.D., Riemann, R., Ruefenacht, B., Salajanu, D., Weyermann, D.L., Winterberger, K.C., Brandeis, T.J., Czaplewski, R.L., Mcroberts, R.E., Patterson, P.L., and Tymcio, R.P., 2008, Mapping U.S. forest biomass using nationwide forest inventory data and moderate resolution information: Remote Sensing of Environment, v. 112, p. 1658-1677. (Also available at http://svinetfc4.fs.fed.us/ rastergateway/biomass/.)

Bliss, N.B., 2003, Soil organic carbon on lands of the Department of the Interior: U.S. Geological Survey OpenFile Report 03-304, 52 p. (Also available at http://egsc. usgs.gov/isb/pubs/openfile/OFR03-304.pdf.)

Cairns, M.A., Brown, Sandra, Helmer, E.H., and Baumgardner, G.A., 1997, Root biomass allocation in the world's upland forests: Oecologia, v. 111, no. 1, p. 1-11.

Canadell, J.G., and Raupach, M.R., 2008, Managing forests for climate change mitigation: Science, v. 320, p. 14561457. 
Comer, Patrick, Faber-Langendoen, Don, Evans, Rob, Gawler, Sue, Josse, Carmen, Kittel, Gwen, Menard, Shannon, Pyne, Milo, Reid, Marion, Schulz, Keith, Snow, Kristin, and Teague, Judy, 2003, Ecological systems of the United States: A working classification of U.S. terrestrial systems: Arlington, Va., NatureServe, accessed November 10, 2009, at http://www.natureserve.org/library/usEcologicalsystems.pdf.

Daubenmire, Rexford, 1968, Plant communities: A textbook of plant synecology: New York, Harper-Row, 300 p.

DeFries, R.S., Field, C.B., Fung, I., Collatz, G.J., and Bounoua, L., 1999, Combining satellite data and biogeochemical models to estimate global effects of humaninduced land cover change on carbon emissions and primary productivity: Global Biogeochemical Cycles, v. 13, no. 3, p. 803-815.

Holsinger, L., Keane, R.E., Steele, B., Reeves, M., and Pratt, S.D., 2006, Using historical simulations of vegetation to assess departure of current vegetation conditions across large landscapes, in Rollins, M.G. and Frame, C.K., The LANDFIRE prototype project: nationally consistent and locally relevant geospatial data for wildland fire management: U.S. Forest Service General Technical Report RMRS-GTR-175, p. 315-366.

Homer, Collin, Huang, Chengquan, Yang, Limin, Wylie, Bruce, and Coan, Micheal, 2004, Development of a 2001 National Landcover Database for the United States: Photogrammetric Engineering and Remote Sensing, v. 70, p. 829-840.

Houghton, R.A., Hobbie, J.E., Melillo, J.M., Moore, B., Peterson, B.J., Shaver, G.R., and Woodwell, G.M., 1983, Changes in the carbon content of terrestrial biota and soils between 1860 and 1980: A net release of $\mathrm{CO}_{2}$ to the atmosphere: Ecological Monographs, v. 53, no. 3, p. 235-262, doi:10.2307/19425.

Houghton, R.A., and Hackler, J.L., 2000, Changes in terrestrial carbon storage in the United States. 1. The roles of agriculture and forestry: Global Ecology and Biogeography, v. 9, p. 125-144.

House, J.I., Prentice, I.C., and Le Quere, C., 2002, Maximum impacts of future reforestation or deforestation on atmospheric $\mathrm{CO}_{2}$ : Global Change Biology, v. 8, p. 1047-1052.

Justice, C.O., Townshend, J.R.G., Vermote, E.F., Masuoka, E., Wolfe, R.E., Saleous, N., Roy, D.P., and Morisette, J.T., 2002, An overview of MODIS land data processing and product status: Remote Sensing of Environment, v. 83, p. $3-15$.
Küchler, A.W., 1964, Potential natural vegetation of the conterminous United States: NewYork, American Geographical Society, Special Publication no. 36, 116 p. (Also available at http://www.ngdc.noaa.gov/ecosys/cdroms/ged_iib/ datasets/b13/ek.htm.)

Natural Resources Conservation Service, 2004, Soil survey laboratory methods manual: Lincoln, Nebr., National Soil Survey Center, Soil Survey Investigations Report no. 42, v. 4.0. (Also available at http://soils.usda.gov/technical/ $\mathrm{lmm} /$.

Pfister, R.D., and Arno, S.F., 1980, Classifying forest habitat types based on potential climax vegetation: Forest Science, v. 26 , no. 1 , p. 52-70.

Pongratz, J., Reick, C.H., Raddatz, T., and Claussen, M., 2009, Effects of anthropogenic land cover change on the carbon cycle of the last millennium: Global Biogeochemical Cycles, v. 23. GB4001 (Also available at http://dx.doi. org/10.1029/2009GB003488.)

Rhemtulla, J.M., Mladenoff, D.J., and Clayton, M.K., 2009, Historical forest baselines reveal potential for continued carbon sequestration: Proceedings of the National Academy of Sciences of the United States of America, v. 106, p. 6082-6087.

Rollins, M.G., 2009, LANDFIRE: a nationally consistent vegetation, wildland fire, and fuel assessment: International Journal of Wildland Fire, v. 18, p. 235-249.

Ruddiman, W.F., 2007, The early anthropogenic hypothesis: challenges and responses: Reviews of Geophysics: v. 45. RG4001 (Also available at http://dx.doi. org/10.1029/2006RG000207.)

Smith, W.B., Miles, P.D., Perry, C.H., and Pugh, S.A., 2009, Forest resources of the United States, 2007: U.S. Forest Service General Technical Report WO-78, 336 p.

U.S. Department of Agriculture (USDA), 2008, U.S. Agriculture and Forestry Greenhouse Gas Inventory: 1990-2005: U.S. Department of Agriculture, Global Change Program Office, Office of the Chief Economist Technical Bulletin No. 1921, 161 p. (Also available at http://www.usda.gov/ oce/climate_change/AFGGInventory1990_2005.htm.)

U.S. Forest Service, 2009, FIA Datamart FIADB 4.0 database: U.S. Department of Agriculture, accessed September 9, 2009, at http://fiatools.fs.fed.us/fiadb-downloads/datamart. html.

Vogelmann, J.E., Howard, S.M., Yang, L.M., Larson, C.R., Wylie, B.K., and Van Driel, N., 2001, Completion of the 1990s National Land Cover Data Set for the conterminous United States from Landsat thematic mapper data and ancillary data sources: Photogrammetric Engineering and Remote Sensing, v. 67, p. 650-661. 
Prepared by the Pembroke, Reston, and Lafayette Publishing Service Centers.

Edited by Debra H. Foster, Marilyn A. Billone, and Beth A. Vairin. Graphics by Christine T. Mendelsohn.

Layout and design by Ann Marie Squillacci.

For more information concerning this report, contact:

U.S. Geological Survey

Office of the Chief Scientist for Hydrology

436 National Center

Reston, VA 20192

or visit our Web site at: http://water.usgs.gov/usgs/nrp/ 

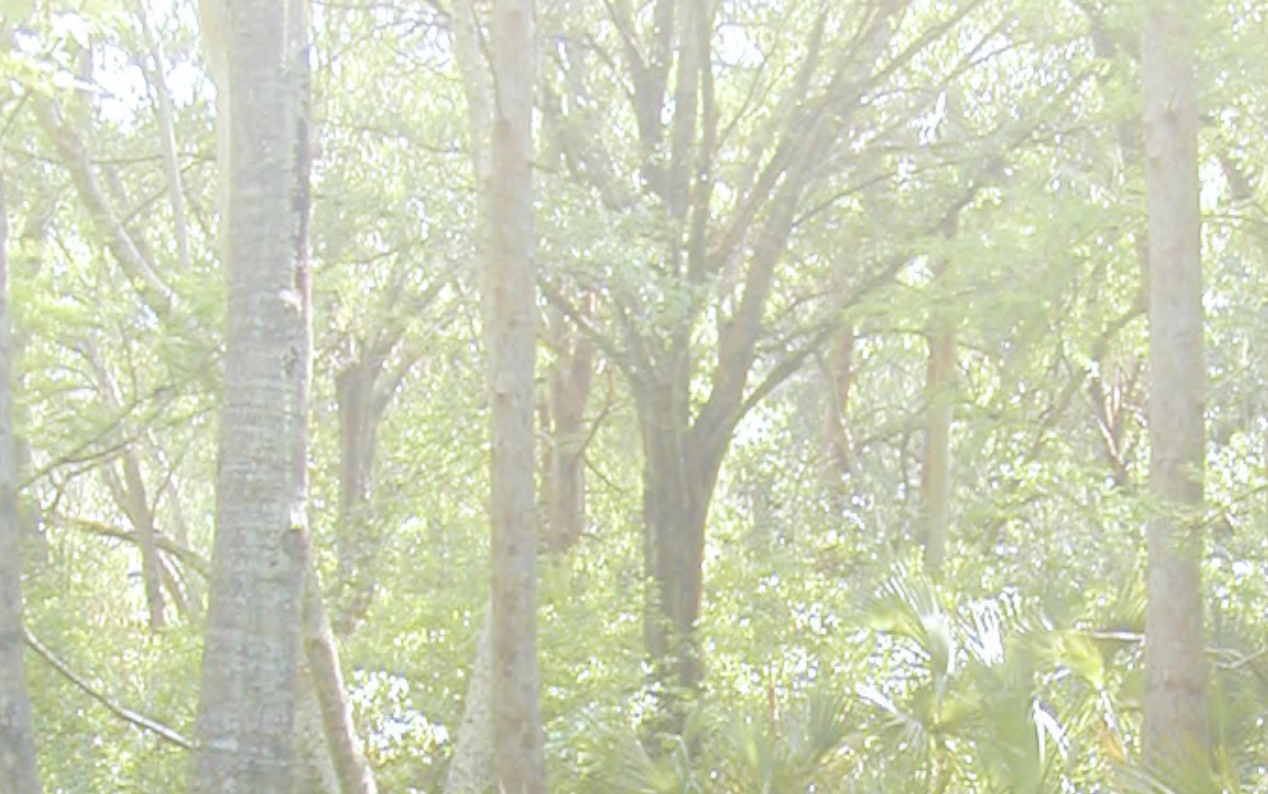

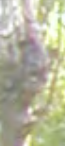

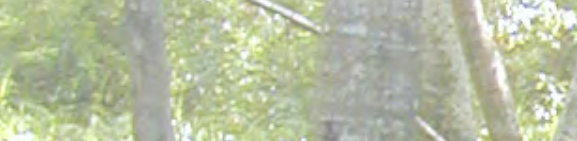

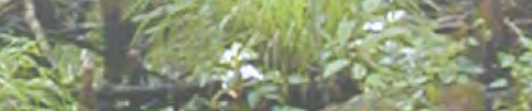

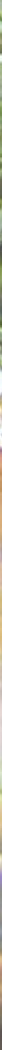

